\title{
Aisthesis
}

Firenze University Press

www.fupress.com/aisthesis

OPEN ACCESS

Citation: R. Ibarlucia (2021) The Bride Machine: Duchamp's Theory of Art Revisited. Aisthesis 14(2): 135-145. doi: 10.36253/Aisthesis-13216

Copyright: (c) 2021 R. Ibarlucia. This is an open access, peer-reviewed article published by Firenze University Press (http://www.fupress.com/aisthesis) and distributed under the terms of the Creative Commons Attribution License, which permits unrestricted use, distribution, and reproduction in any medium, provided the original author and source are credited.

Data Availability Statement: All relevant data are within the paper and its Supporting Information files.

Competing Interests: The authors have declared that no competing interests exist.

\section{The Bride Machine: Duchamp's Theory of Art Revisited}

\author{
Ricardo Ibarlucia \\ CONICET- Centro de Investigaciones Filosóficas and Universidad Nacional de San \\ Martín (Argentina) \\ ribarlucia@conicet.gov.ar
}

\begin{abstract}
It is a commonplace in certain areas of art theory and contemporary art practices to consider Marcel Duchamp's ready-mades as ordinary objects, which have an artistic value that depends more on a theoretical or institutional framework than on an aesthetic experience. The aim of this paper is, on the one hand, to show the historical emergence of these artifacts on the light of the impact of the industrial production in avant-garde movements of the early twentieth century. Discussing Walter Benjamin's and Jean Brun's, it argues that Duchamp's practice has an explanatory principle, both in the mechanical reproduction of the work of art and in the aestheticization of the machine. On the other hand, it brings forward some observations regarding Duchamp's insight on the "total lack of good or bad taste" and the perceptual dimension of a sculptural object as the Large Glass, coming back to Arthur Danto's interpretation of ready-mades and to the notion of "implementation" introduced by Nelson Goodman to define "the process of bringing about the aesthetic functioning that provides the basis for the notion of a work of art".
\end{abstract}

Keywords: Ready-made, Large Glass, Technlogical Reproductibility, Aesthetic properties, Implementation.

\section{INTRODUCTION}

There is a photo of the First International Dada Fair in 1920 which shows Raoul Hausmann and John Heartfield holding a banner with an inscription in German: "Art is Dead. Long Live Tatlin's New Machine Art!» (Hausmann [1972]: 44, 120)1. With this phrase, Dadaists from Berlin not only expressed their commitment to the Russian Revolution in paying tribute to Vladimir Tatlin's Monument to the Third International, but they also proclaimed an idea that summarised a common aspiration for avant-garde artists. Some of them pondered the aesthetic value of machines regardless of their utilitarian value; others, the function that form of art could assume

${ }^{1}$ Unless stated otherwise, all translations quoted in this article are my own. 
in the construction of socialism: all of them were conscious of the profound changes artistic forms were experiencing as an effect of the deployment of the techniques of production and reproduction in the modern industrial society.

On the pages that follow, I intend to examine Marcel Duchamp's seminal developments in the field of plastic arts against the backdrop of such machine art. My approach is both theoretical and historical. In its general outline, it differs from the contemporary outlook on the works produced by Duchamp during his Dadaist and Surrealist period as precursors of conceptual art. At the same time, it turns away from the reductive interpretation of Duchamp's ready-mades as ordinary manufactured objects, whose artistic status is decidable in the context of a given theory of art or institutional system, with independence from their perceptual and formal properties. The thesis I defend is that Duchamp's idea of artwork can be explained by two converging effects the developments of industrial production had over artistic practices, both of which have been pointed out by Walter Benjamin in his essay The Work of Art in the Age of its Technological Reproducibility (1935-1936): the birth of new artistic forms - such as photography and film - and their repercussion on «art in its traditional form» (Benjamin [2012]: 55, 98, 164, 210).

I argue that an sculptural object like the Large Glass (1915-1923), which exemplifies Benjamin's notion of the "assembled artwork» (montierbar Kunstwerk) from the industrial age in the field of plastic arts (Benjamin [2012]: 32, 66, 111-112, $176)$, can be considered as an expression of the «aestheticization of the machine» that Jean Brun has studied with regard to Italian Futurism and other artistic movements from the beginning of the $\mathrm{xx}^{\text {th }}$ century (Brun [1992]: 258-274). To show this, my reasoning will unfold in three steps. First, I will give a historical account of the avant-garde fascination with the aesthetic potential of the machines. Then, I will focus on Francis Picabia and Marcel Duchamp to show how their works extol to the point of erotization the perceptual and formal properties of mechanisms, devices and products manufactured for massive use and con- sumption. Finally, I will advance some ideas on what could be seen as a pragmatics of the aesthetic object, recovering what Nelson Goodman called «implementation» in order to define "the process of bringing about the aesthetic functioning that provides the basis for the notion of a work of art» (Goodman [1982]: 282, [1984]: 145).

\section{FUTURE BEAUTY}

A good starting point for what I aim to prove here is no doubt the eulogy Filippo Tommaso Marinetti, in his famous Manifesto of 1909, dedicates to the «beauty of speed» as a new aesthetic quality: «A race car with a hood adorned with great pipes resembling serpents of explosive breath - a roaring car that seems to ride on grapeshot is more beautiful than the Victory of Samothrace» (Marinetti et al. [1914]: 6).

The artistic revolution promoted by Italian futurism - as Brun observes - takes part in the faith on technical progress and endows the machine with «the ontological status of a true living creation which dispenses new orgasms, born from the coupling of man with a manufactured Galatea» (Brun [1992]: 261). Stripped of «all utilitarian and social aspects», the machine is seen not only as "a fine work of art" but also as a young vestal, «a seductive beauty that has reached puberty and has finally gotten to be nubile» (Brun [1992]: 261-262). This awakening to «beauty and femininity of the loved machine as the Virgin to be taken», Brun continues, «reinforces or gives birth to a double current of ideas which has capital repercussions»: one is developed in Russia; the other one, in Western societies, "where the machine is not glorified as Generatrix but as Mesalina» (Brun [1992]: 266).

Let me revise this thesis in the light of the effects that, according to Benjamin, industrial production has over the concept of art, shattering what he calls «the Hydra of aesthetic scholasticism with its seven heads: creativity, empathy (Einfühlung), timelessness, recreation, compassion, illusion, and artistic enjoyment» (Benjamin [2011]: 1, 308). In 1912, Vladimir Maiakovski declares him- 
self a futurist and endorses the famous manifesto of the Cubo-Futurist Hylaea group A Slap in the Face of Public Taste, in which «the New Coming Beauty of the Self-sufficient (self-centered) Word» is exalted (Burliuk et al. [1988]: 52). Two years later, after Marinetti's tour to Saint Petersburg and Moscow, Russian avant-garde magazines with typographical games multiply, spelling and punctuation rules are suppressed, and a new language with its own phonetics, morphology, and syntax called zaum - is proposed.

During the first years after the Russian Revolution, the Futurist aesthetic converges with the construction of socialism. Not even Marinetti's affiliation to the Italian Fascist Party, in 1919, proves to be an impediment for Soviet leftist artists to make their own, both his charge against bourgeois art and his praise of the machine; such is the case as much for UNOVIS (New Art Vindicators) Suprematists and the Constructivists, as it is for the Productivists from the Vkhutemas (Higher Art and Technical Studios), who openly declare: «Down with art, long live technical science!» (Benton et al. [1975]: 91-92).

In the liberal democracies of Western Europe, Futurist ideas have at least three main derivations. Guillaume Apollinaire writes his manifesto Futurist Anti-Tradition, dated - parodying Friedrich Nietzsche - in «Paris, July $30^{\text {th }}$, Grand Prix Day, 65 meters above Saint-Germain Blvd» (Apollinaire [1913]: 3) ${ }^{2}$. This «Manifesto-Synthesis» conceives of Futurism as the "the motor for all tendencies: Impressionism, Fauvism, Cubism, Expressionism, Pathetism, Dramatism, Orphism, Paroxysm» (Apollinaire [1913]: 1). In the first section, entitled Destruction, he calls for the suppression of "poetic sorrow, snob exoticisms, copying in art, [...] the sublime in art» (Apollinaire [1913]: 1). The second section, Construction, has two parts:

\footnotetext{
2 The sentence refers to a passage from Ecce Homo, published posthumously in 1908, where the German philosopher says he first registered "the thought of eternal return», the fundamental notion of Thus Spoke Zarathustra (1885), in a piece of paper, at the bottom of which he wrote: «6000 feet above man and time» (Nietzsche [19671982] 5: 333).
}

Techniques Continually Renewed («words in freedom», «onomatopoeic descriptions», «art of noises», «machinism», «art of journeys») and Intuition, Speed, Ubiquity («wireless imagination», "physical transcendentalism», «analogies and puns») (Apollinaire [1913]: 2).

In London, the first exposition of Futurist painters takes place in 1912. The works of Umberto Boccioni, Gino Severini Carlo Carrà and Luigi Russolo have an impact on Christopher Nevinson, coauthor with Marinetti of Vital English Art (1914). In this manifesto, they defend a «strong, virile, anti-sentimental» art against «the cult of tradition and academic conservatism», "commercial conformism», «the purely ornamental», «corniness", "the old and grotesque idea of genius» and «the mania of immortality» (Rainey et al. [2009]: 196-198). In contrast to Nevinson's enthusiasm, Wyndham Lewis, founder of BLAST, the literary magazine of the Vorticist movement in Britain, does not conceal his disdain for the «Melodrama of Modernity», imported by some «fanciful but rather conventional Italians», enthroning an "Impressionism up-to-date», to which Marinetti has added «his Automobilism and Nietzsche stunt» (Lewis [1914]:143-144).

In Weimar's Germany, one can recognize two converging tendencies. One of them is represented by the Bauhaus founded by Walter Gropius, who defended the idea of «a new guild of craftsmen, without the class distinctions that raise an arrogant barrier between craftsman and artist» (Gropius [1919]: 3). The program of this avant-garde school for artists and industrial designers promoted the building of the future society through «a resolute acceptance of the living environment of machines and vehicles» and «the organic creation of objects following their own present-day laws, without embellishments or romantic adornment» (Gropius [1925]: 6). The other tendency shows a programmatic convergence between Berlin Dadaism and El Lissitzky Productivism. The so-called «G-Group» opposed the experimental notion of Gestaltung (design, form-creation) to that of style, relied on "predetermined formal motives», and sought «to discover and forge a natural language 
that would be objective, scientific, collective, universal, and comprehensible to all» (Mertins and Jennings [2010]: 6).

Werner Gräff, co-founder of the magazine G-Materialen für Elementaren Gestaltung, in which Benjamin would later contribute ${ }^{3}$, attempts to redefine the Wagnerian concept of Gesamtkunstwerk in the terms of a "partnership between architecture, sculpture and painting (together with) industry and technology» (Gräff [1922]: 74). In turn, Lázló Moholy-Nagy argues for the need to spread the use of technical appliances, regularly employed with reproductive aims, for "productive purposes» (Moholy-Nagy [1922]: 236). The means he intends to research "under the conditions of a lab-experimental study» are the gramophone, photography, and cinema (Moholy-Nagy [1922]: 237).

According to Moholy-Nagy, the extended use of the gramophone, employed only to reproduce already existing acoustic phenomena, could contribute to a renewal of musical composition, to the invention of new instruments and to the «development of inexistent sounds and inexistent tonal relations» (Moholy-Nagy [1922]: 237). The photo camera, solely used to "capture (reproduce) individual objects, as reflected or absorbed light», could be used «along with a mirror - or an optical device, etc.» to record different light phenomena, «the same way telescopes do with stars or X-ray images». As for the "cinematic practice», which is mostly limited to reproducing dramatic actions or to record movements (animal, human and mechanical) in the case of scientific films, could now be oriented to the formation of a "game of creation of its own», as in Hans Richter's or Viking Eggeling's short abstract animation films (Moholy-Nagy [1922]: 237).

\section{THE EROTIZATION OF THE MACHINE}

According to Brun's approach, the second strand of aesthetic ideas fuelled by Italian Futur-

\footnotetext{
${ }^{3}$ Benjamin translated into German La photographie à l'envers, the preface by Tristan Tzara to Man Ray's album of rayographs Les champs délicieux (1922). See Benjamin [1972-1999] Supl. I: 9-10).
}

ism moves between Paris and New York and leads from Francis Picabia and Marcel Duchamp to the threshold of Surrealism: «the aestheticization of the machine», transformed into the «object of all oneiric crystallizations», results in its «erotization», replacing the model who posed naked in the painter's atelier (Brun [1992]: 266).

The futurists' condemnation of the static nude in painting - "as sickening and depressing as adultery in literature» - and their celebration of «dynamic sensations» of movement and light (Boccioni et al. [1910]) speak eloquently of the repercussion of machinism on artistic forms pointed out by Benjamin. Those paintings of the dawn of the twentieth century that seek to represent the dynamism of a cyclist, a football player, a motorcycle or a car - such as the Étienne Jules Marey's chronophotographs - show the way in which Italian Futurism - even before Dadaism - already strives to "produce with the means of painting (or relatedly literature) the effects» what cinema will be able to produce naturally (Benja$\min$ [2012]: $85,134,192$, emphasis in the original).

In the case of Francis Picabia, the erotization of the machine is born when he discovers New York City in 1913, "the only Cubist city in the world [...] the futurist city» (Picabia, [2005]: 49, 53). Already familiarised with Giorgio de Chirico's mannequins, Fernand Léger's robotic figures and Alexandr Archipenko's sculpture-paintings, his contact with avant-garde artists from Manhattan -Alfred Stieglitz, Paul Marius de Zayas, Paul Haviland - is the starting point for his first «mechanical paintings»: Catch as Catch Can, Negro Song, Ballerina on an Ocean Liner, New York, Edtaonisl (Eclessiastic) and Undina, among others (see Sanouillet [1964]: 24; Camfield [1966]).

In 1915 Picabia joins the journal 291, which is conceived as «a lab, a place for experiments» oriented to forge a new visual language (Stieglitz [1915-1916]: 1, 4). There, he publishes a series of «object-portraits», inspired in popular mechanics handbooks: Stieglitz as a photographic camera (Here, Here is Stieglitz, Faith and Love), himself as a strange dysfunctional mechanism (Canter), a 
naked young woman as a spark plug (Portrait of an American Girl in a State of Nudity), Marius De Zayas as a sewing machine (De Zayas! De Zayas!), Haviland as an electric lamp (Voilà Haviland) (Stieglitz [1915-1916]: 5-6, 1-3). In explaining the new orientation of his work, Picabia declares:

I have been profoundly impressed by the vast mechanical development in America. The machine has become more than a mere adjunct of human life. It is really a part of human life -perhaps the very soul. In seeking forms through which to interpret ideas or by which to explore human characteristics I have come at length upon the form which appears most brilliantly plastic and fraught with symbolism. I have enlisted the machinery of the modern world and introduced it into my studio. (Macmonnies [1915]: 2).

As regards Duchamp specifically, I argue that the process of erotization of the machine is inseparable from his gradual abandonment of painting. According to him, eroticism could replace what in the history of art is called Symbolism or Romanticism: «[...] if eroticism is used as a principal basis, a principal end, then it takes the form of an 'ism', in the sense of a school» (Cabanne [1967]: 167).

Retrospectively, Duchamp's plastic experimentation seems to cover four stages guided by the same conscious pursuit of producing works increasingly emancipated from pictorial depiction. The first phase can be taken to begin with Coffee Mill (1911), a painting that opens «a window to something else», according to his own words (Cabanne [1967]: 43), given the fact that it deviates from the Post-Impressionism that was characteristic of his previous works: the representation of that domestic tool is not in conformity with the imitative principle anymore, but instead its mechanical possibilities - the moments of the handle's turning - are indicated with an arrow.

The second stage could be illustrated by the two successive versions of Nude Descending a Staircase (1911-1912), in which there is a convergence of interests that go beyond Futurism and Cubism, «among them the cinema, still in its early days, and the separation of the static positions in Marey's chronophotographs in France and in
[Thomas] Eakins and [Eadweard] Muybridge in America» (Duchamp [1994]: 246). According to Duchamp, this painting aspired to a decomposition of forms more radical that the one operated by Cubism and, in spirit, it was closer to the common studies of moving horses and of fencers in different positions than to the dynamism of Futurist plastics or Robert Delaunay's Simultaneism, both approaches in which he saw "an Impressionism of the mechanical world», situated on the opposite side of his desire to "get away from the physical aspect of painting» and to put it once again «at the service of the mind» (Sweeney [1946]: 20).

Now, and this is meant to support the interpretation proposed at the beginning of this essay, the invention of the ready-made can be considered to give rise to the third stage of the process I have been describing: "An ordinary object elevated to the dignity of a work of art by the mere choice of the artist», according to Duchamp's quotation collected in the Abridged Dictionary of Surrealism (Breton \& Éluard [1938]: 23). His purpose with Bicycle Wheel (1913), Bottle Rack (1914), Fountain (1917), and another dozen of «assisted» or «reciprocal» ready-mades (Duchamp [1994]: 209-210] was to start getting rid of the «retinal inheritance» of a plastic art based on optic impressions and on the object's sensual qualities, and propose, instead, one based on the "grey matter", in the same way that paintings from the Italian Renaissance, where "the idea was to glorify a religion, the Catholic religion, the Catholic God or other, in short, but the painting side itself, the retinal side of the painting was very secondary ... more than secondary (Duchamp [2002]) .

\footnotetext{
${ }^{4}$ In an interview conducted in 1963 and published after his death, Duchamp suggested the following relationship between ready-mades and the industrial products the painter usually manipulates: «A ready-made is a work of art without an artist to make it, if I may simplify the definition. A tube of paint that an artist uses is not made by the artist; it is made by the manufacturer that makes paints. So the painter really is making a ready-made when he paints with a manufactured object that is called paints. So that is the explanation, but when I did it, it was
} 
The historical reference to Renaissance art is particularly significant. Duchamp is not rejecting painting tout court, but distancing himself from Romanticism, Gustave Courbet's realism, and certain pictorial currents of the late 19th century - Impressionism, Divisionism (or Chromoluminarism), Pointillism - which were intended to be based on advances in optics and the scientific theories about colour. Both Cubism and Parisian Dada played a decisive role for the constitution of his own view of modern art. For Duchamp, the latter was «an extreme protest against the physical side of painting» and its «metaphysical attitude» was «a sort of nihilism» that served as a salutary and purgative tabula rasa (Sweeney [1946]: 20).

Finally, in the Large Glass (1915-1923), Duchamp's interest on manufactured objects meets two mechanist reveries of fin-de-siècle Symbolism (see Carrouges [1954]: 27-59). One of them is the novel The Supermale, by Alfred Jarry, in which there is a description of a "Love-InspiringMachine», an electromagnetic device conceived of to satisfy a male's sexual appetites and to contribute to «the biggest safeguarding of bourgeois science, medicine and humanity» (Jarry [1902]: 236-237). The other one is the scenic version of Raymond Roussel's Impressions of Africa, which Duchamp saw in the Théatre Antoine in 1912. More than thirty years later, Duchamp would confess:

It was fundamentally Roussel who was responsible for my glass, La Mariée mise à nu par ses célibataires, même. From his Impressions d'Afrique I got the general approach. This play of his, which I saw with Apollinaire, helped me greatly on one side of my expression. I saw at once I could use Roussel as an influence. I felt that as a painter it was much better to be influenced by a writer than by another painter. And Roussel showed me the way. (Sweeney [1946]: 21)

We cannot know which specific elements of Roussel's performance had an influence on the

not at all intended to have an explanation. The iconoclastic part of it was much more important» (Duchamp [1968]: 47). For a discussion of this answer, see Duve [1996]: 159-166.
Large Glass. In an interview Duchamp only said: «It was something formidable. There was a snake on stage and a mannequin that slightly moved, it was a totally extraordinary mad thing. I cannot remember much of the text» (Cabanne [1967]: 5-6). Critics have argued that he was inspired by the character of Louise Montanesco, who invented a painting machine which «aimed to obtain, by means of a purely photographic procedure, a driving force accurate enough to guide with precision a pencil or a brush» (Roussel [1910]: 402; see Allington [2002]).

Other commenters have suggested a third equally plausible source: the short story In an Automobile by Maurice Maeterlinck, collected in 1904 in The Double Garden (see Clair [1987]:7779). There are certainly some significant resemblances between Maeterlinck's metaphorical depiction of the car's physiology and the «nickel and platinum» machine of Duchamp's journey through the Jura-Paris route that would have inspired The Bride Stripped Bare by Her Bachelors, Even:

Its soul is the electric spark, which, seven or eight hundred times to the minute, sends fiery breath through the veins. And the terrible, complex heart is composed, first of all, of the carburetter, with its strange double face: the carburetter, which prepares, proportions and volatilizes the petrol-subtle fairy that has slumbered ever since the world began, and is now recalled to power, and united to the air that has torn her from sleep. (Maeterlinck [1904a]: 54, [1904b]: 174; see Duchamp [1994]: 46-47)

\section{LEONARDO AND THE READY-MADES}

In the Green Box (1934), Duchamp focuses on the structure of the "celibate-machine» and its operating mode. The description he gives of the Large Glass seems to combine the attributes of Maeterlinck's car's engine with Jarry's «LoveInspiring machine» and Roussel's picto-photographic machine:

The Bride is first basically a motor. But a motor that transmits its timid power - she is this very timid 
power. This timid power is a sort of automobiline, an essence of love, which once distributed through the engine of soft cylinders, when it makes contact the sparkles of its constant life, it serves to the blossoming of this virgin who has reached the goal of her desire. (Duchamp [1994]: 67, crossed out and underlined in original).

The «cinematic blossoming», «fulfilment» or «culmination» [épanouissement], the apotheosis of the Bride's orgasm is the «m[ost] important part of the painting», according to Duchamp: «It is, in general, the halo of the Bride [...], the whole of her splendid vibrations» (Duchamp [1994]: 68). In graphic terms, Duchamp does not aim to «symbolize with an exalted painting this happy ending», but to make "an inventory of the elements of this wholeness, elements of the sex life imagined by the desiring bride» (Duchamp [1994]: 68) using the photos of draught pistons that crown the upper part of the Large Glass.

The Bride Stripped Bare by Her Bachelors, Even... would represent the coronation - and even the systematization - of Duchamp's research on the machine. The criticism of retinal art is consummated in the suppression of the qualities traditionally attributed to the work of art, that is, through the bracketing not of every perceptual quality of the object, as commonly stated, but of those qualities prescribing its exclusive optic reception. Duchamp has given us two well-known descriptions of this operational technique. In one of them, he argues: "You have to achieve something so indifferent that you have no aesthetic emotion. The choice of ready-mades is always based on visual indifference and, at the same time, on the total lack of good or bad taste» (Cabanne [1967]: 83-84). In the other one, he states more precisely:

A point that I want to establish very clearly is that the choice of these ready-mades was never dictated by aesthetic delectation. The choice was based on a reaction of visual indifference combined at the same time with a total absence of good or bad taste... in fact a complete anaesthesia. (Duchamp [1994]: 209, emphasis in the original).
Arthur Danto is absolutely correct when he states that the "overcoming of taste was the achievement of Duchamp's ready-mades»; he is not, however, when he deduces from it «the most radical dissociation of aesthetics from art» (Danto [2000]). A restriction must be imposed: Duchamp' conception of art has certainly detached from the traditional aesthetics grounded on the notion of beauty as pure form, namely, the aesthetic theory from Kant to Clement Greenberg, according to Danto himself (see Danto [2007]: 123-127). Historically, Duchamp's anti-aesthetic rebellion has displayed the enfranchisement of modern art from the ideal of beauty and has legitimated the exploitation of a plurality of aesthetic qualities within the field of artistic practices. But one further specific remark needs to be made regarding Duchamp's quote: the indistinction between conventional and unconventional materials - what he calls «a total absence of good or bad taste... in fact a complete anaesthesia $»^{5}$ - refers explicitly here to the process of gestation and creation of the artwork, not to its reception.

In the words of Nelson Goodman, one might say that the «execution» of a work of art should not be confused with its «implementation» or «activation», which consists in making «the work works» (Goodman, [1982]: 281, [1984]: 141-143) ${ }^{6}$. This discrimination is important to understand the operational technique of the ready-made, given the fact that the neutralization of visual stimuli pointed out by Duchamp -the highlighted «visual indifference» - is relevant to the making of an object or the choice of an object, which could be anything. From the artistic point of view, what Duchamp seems to seek is the replacement of the spectator's passive attitude with a way of reception that restores an active role to her/him. To support this hypothesis, we could quote what Duchamp himself writes in the the Green Box about such an interplay:

\footnotetext{
${ }^{5}$ On the "anaesthetics of the ready-made", see Oyarzún [2000]: 42-122.

${ }^{6}$ For the application of the last notion to the "indirect activation" of technical the reproduction of artworks, see Goodman (1992). A seminal discussion of his whole argument can be found in Cometti [2000].
} 
After all, the artist is not the only one accomplishing the act of creation, because the spectator establishes the work's contact with the outside world by deciphering and interpreting its underlying qualification and thus [he/she] makes his/her own contribution to the creative process. (Duchamp [1994]: 207)

To put it in Benjamin's words, by displacing «optic reception», ready-mades promote a «tactile reception», which is shaped more by use than by attention (Benjamin [2012]: 33, 88-89, 138-139, 195-196, 246-247). Far from neutralizing the spectator's sensory stimuli, they multiply and expand them cinematically, like the Bride's orgasm does in the Large Glass. The aesthetic over-excitation counterbalances the anaesthetizing process that perception is subjected to in the mechanized world, that is, "the crisis in cognitive experience caused by the alienation of the senses», as characterized by Susan Buck-Morss in her reading of Benjamin's essay on the artwork (Buck-Morss [1992]: 37). Seen from this angle, the ready-made would be a sort of mechanism that, when activated, releases a "play space [Spielraum]», a ludic dimension which restores perception, giving way to imagination and interplay, as well as to the physical experience the spectator has with the object (Benjamin [2012]: 151, 155-156, 174).

Among his notes for The Work of Art in the Age of its Technological Reproductibility, Benjamin makes a clever remark on the content of the Green Box, stressing «the competition between photography (film) and painting as the explanatory principle» of Duchamp's plastic experimentation, "one of the most interesting phenomena of the French avant-garde» (Benjamin [2012]: 275). Although his production is extremely limited and he cannot be pigeonholed in a school, his influence is not at all small, says Benjamin, especially among Surrealists:

His theory of art's value, which he has recently exemplified (not explained) in a box of documents, La Mariée mise à nu par ses célibataires, looks something like this: from the moment I gaze upon an object as an artwork, it ceases completely to function as such. Today's man can experience much better the specific effect of a work of art in fortuitous configurations in oxtricter in things objects extricted objects (namely, objects that have been removed from their functional context: a piano keyboard with an indoor plant placed above it, a top hat with multiple perforations) than in works of art certified as such. (Benjamin [2012]: 275-276, crossed out in original)

Because of Duchamp's authority, Benjamin adds, the making of this kind of objects has become a «passionate activity» among Surrealists, in which, through chance, oxidation and discarding, «a great play space» is opened (Benjamin [2012]: 276). There will be those who qualify these practices as decadent; however, they possess a «diagnostic value» (Benjamin [2012]: 276). In his plastic exploration, Duchamp seems to have followed the advice Da Vinci used to give to his disciples, often «lost in the search for models», when he suggested exercising their imagination in front of a wall covered with moisture (Benjamin [2012]: 276). Benjamin refers to one of the famous precepts of Leonardo's Treatise on Painting, where he states:

Look at walls splashed with several stains, or stones of various mixed colours. If you must invent some scene, you can see there are resemblances to several landscapes, adorned with mountains, rivers, rocks, trees, great plains, valleys, and hills, in various ways. Also, you can see various battles, and lively postures of strange figures, expressions on faces, costumes, and an infinite number of things, which you can reduce to good integrated form. This happens on such walls and varicoloured stones, (which act) like the sound of bells, in whose pealing you can find every name and word that you can imagine. (Fumagalli [1953]: 250; Da Vinci [2008]:173)

\footnotetext{
7 This paragraph from the Treatise on Painting is often quoted by Surrealist - among others, André Breton [1933]: 161-162 and Max Ernst [1948]: 3. Remembering the psychologists of art have always been fascinated by this precept, Ernst H. Gombrich suggests that DaVinci «could deliberately induce in himself a state of dreamlike loosening of controls in which the imagination began to play with blots and irregular shapes», helping him in turn to enter in «the kind of trance in which his inner visions
} 
From age to age, argued Leonardo, painting declined «because everyone imitated the pictures that were already done» (Fumagalli [1953]: 251; Da Vinci [2008]: 214). Hence the "new device for study", the speculative method he recommends to his disciples, aims to revert this tendency; as «trivial and almost ludicrous» it may seem, it is «extremely useful in arousing the mind to various inventions» and for creating original works of art (Fumagalli [1953]: 250; Da Vinci [2008]:173). According to Da Vinci, artists should not take as standard anything other than nature - «the mistress of all masters» (Fumagalli [1953]: 250; Da Vinci [2008]: 214). Nature should be their true teacher and guide. Likewise, in its vivid and spontaneous forms, I would dare say, Duchamp took the second nature of the machine as the model for his ready-mades.

\section{CONCLUSIONS}

Duchamp's contribution to contemporary art does not lie in turning the work of art into an ontologically neutral object, as it seems to be quite accepted in some circles of art criticism and art practices. His ready-mades are not merely ordinary objects, in the sense of a theory according to which the artistic status of an object is independent from its perceptual and formal qualities and definable only by virtue of its social or institutional context. Such arguments, I would like to underline, apply even further hardly to an allegorical installation or sculptural artifact as the Large Glass, whose artistic properties are both perceptible and imperceptible, a part of the physical object and a part of the "embodied meaning», to borrow Danto's famous expression (see Danto [1994]; [2007]: 125; [2013]: 37, 39-40).

The so-called «artworld»- even in the initial interpretation of Danto as «an atmosphere of artistic theory, a knowledge of the history of art» (Danto [1964]: 580) - does not pre-exist artworks and artistic practices as an ensemble of codi-

would be projected on to external objects» (Gombrich [1966]: 61). fied rules that externally provide the criteria for their identification, interpretation, or evaluation. It is not a receptacle containing the conventional definitions of art, but a pragmatic framework for activating artworks, which may be in opposition to the standardized conception of art in a specific historical period and modulate the aesthetic qualities considered to be non-artistic.

This would be my first corollary. The second one is related to the "theory of art's value» Benjamin finds in the Green Box: «from the moment I gaze upon an object as an artwork, it ceases completely to function as such» (Benjamin [2012]: 275-276). In Goodman's terms, the problem has to do with «the process of bringing about the aesthetic functioning that provides the basis for the notion of a work of art» (Goodman [1982]: 282; [1984]: 145). The pragmatics of the ready-made, as I hope I have demonstrated, shows that «implementation» allows not only a work of art to function as such, but also any other object to do so, from a urinal or a bicycle wheel to the cracks and moisture stains on a wall.

In short, the concept of artwork Duchamp seems to have forged from his research on machines does not depend upon a definition of art but upon a reflection on the object's aesthetic functioning. Looking ahead, I wonder whether what we now call «artworld» - with its high degree of institutionalization, its criticism, and its increasingly professionalized audiences - favours this functioning, or if art rather takes place outside of this circle, as Duchamp and many of his contemporaries thought.

\section{REFERENCES}

Allington, E., 2002: Dream Machines, "Frieze" 66, pp. 58-93.

Apollinaire, G., 1913: L'Antitradition futuriste. Manifeste-Synthèse, Direction du Mouvement Futuriste, Milano.

Benjamin, W., 2012: Das Kuntswerk im Zeitalter seiner technischen Reproduzierbarkeit, ed. by B. Lindner, S. Broll, J. Nitsche, Suhrkamp, Berlin. 
Benjamin, W., 2011: Kritiken und Rezensionen, ed. by H. Kaulen, 2 vols., Suhrkamp, Berlin.

Benjamin, W., 1972-1999: Gesammelte Schriften, ed. by R. Tiedemann, H. Schweppenhäuser, in collaboration with T.W. Adorno and G. Scholem, 7 vols. (14 parts) and 3 supplements, Suhrkamp, Frankfurt a. M.

Benton, T., Benton, C., Sharp, D. (eds.), 1975: Form and Function. A Source Book for the History of Architecture and Design 1890-1939, Crosby Lockwood Staples, London.

Boccioni, U., Carrà, C.D., Russolo, L., Balla, G., Severini, G., 1910: La pittura futurista. Manifesto tecnico, Uffici di Poesia, Milano.

Breton, A., Éluard, P., 1938: Dictionnaire abrégé du surréalisme, José Corti, Paris, 1991.

Breton, A., 1933: Le message automatique, in Point du Jour, nouvelle édition revue et corrigée, Gallimard, Paris, 1992, pp. 159-182.

Brun, J., 1992: Le rêve et la machine: technique et existence, Paris, La Table Ronde.

Buck-Morss, S., 1992: Aesthetics and Anaesthetics: Walter Benjamin's Artwork Essay Reconsidered, "October" 62, pp. 3-41.

Burliuk, D., Kruchenykh, A., Mayakovsky, V., Khlebnikov, V., 1988: Slap in the Face of Public Taste, in Lawton, A., Eagle, H. (eds), Russian Futurism through Its Manifestoes, 1912-1928, Cornell University Press, Ithaca NY, pp. 51-52.

Cabanne, P., 1967 : Entretiens avec Marcel Duchamp, Belfond, Paris.

Camfield, W. A.,1966: The Machinist Style of Francis Picabia, "The Art Bulletin" 3-4, pp. 309-322.

Carrouges, M., 1954: Les machines célibataires, Éditions des Arcanes, Paris.

Clair, J., 1987: De quelques métaphores automobiles, "Revue de l'Art" 77, pp. 77-79.

Cometti, J.-P., 2000: Activating Art, "Journal of Aesthetics and Art Criticism" 58, pp. 237-243.

Danto, A.C., 1964: The Artworld, "The Journal of Philosophy" 61 (19), pp.: 571-584.

Danto, A. C., 1994: Embodied Meanings: Critical Essays and Aesthetic Meditations, Farrar, Straus, and Giroux, New York.

Danto, A. C., 2000: Marcel Duchamp and the End of Taste. A Defense of Contemporary Art,
"Tout-Fait.com: The Marcel Duchamp Studies Online Journal" 1 (3), https://www.toutfait. com/issues/issue_3/News/Danto/danto.html

Danto, A. C., 2007: Embodied Meanings, Isotypes, and Aesthetical Ideas, "The Journal of Aesthetics and Art Criticism" 65 (1-Special Issue), pp. 121-129.

Danto, A. C., 2013: What Art is?, Yale University Press, New Haven-London.

Da Vinci, L., 2011: Notebooks, ed. by I. A. Richter, T. Wells, pref. by M. Kemp, Oxford University Press, Oxford.

Duchamp, M., 1994: Duchamp du signe, ed. by M. Sanouillet, P. Matisse, P., Flammarion, Paris.

Duchamp, M. 1968: I Propose to Strain the Laws of Physics, "ARTnews" 67, pp. 46-47.

Duchamp, M., 2002: Changer de Nom, simplement (Interview de Marcel Duchamp à la Radio Télévision canadienne, le 17 juillet 1960), “ToutFait.com: The Marcel Duchamp Studies Online Journal" 2 (4): https://www.toutfait.com/issues/ volume2/issue_4/interviews/interviews.html.

Ernst, M., 1948: Beyond Painting, in Ernst, M., (ed.), Beyond Painting and Other Writings by the Artist and his Friends, transl. by D. Tanning, pref. by R. Motherwell, Wittenborn, Schulz, New York, pp. 3-19.

Fumagalli, G., 1953: Leonardo, omo sanza lettere, Sansoni, Firenze.

Goodman, N., 1984: Of Mind and Other Matters, Harvard University Press, Cambridge MA.

Goodman, N., 1982: Implementation of the Arts, "The Journal of Aesthetics and Art Criticism" 40 (3), pp. 281-283.

Goodman, N., 1992: L'Art en action, in Cometti, J.-P, Morizot, J., Pouivet, R. (eds.), Esthétique contemporaine: Art, représentation et fiction, transl. by J.-P. Cometti, Librairie Philosophique, Paris, 2005, pp. 143-157.

Gombrich, E. H., 1966: Norm and Form: Studies in the Art of the Renaissance, Phaidon, London.

Gräff, W., 1922: Für das Neue, "De Stijl” 5, pp. 74-75.

Gropius, W., 1925: Grundsätze der Bauhausproduktion, in Neue Arbeiten der Bauhauswerkstätten (Bauhaus Bücher 7), Albert Langen, München, pp. 5-8. 
Gropius, W., 1919: Programm des Staatlichen Bauhauses in Weimar, in Programm des Staatlichen Bauhauses von Walter Gropius und dessen Versendung. Landesarchiv ThüringenHauptstaatsarchiv Weimar, Staatliches Bauhaus Weimar.

Hausmann, R., 1972: Am Anfang war Dada, ed. by K. Riha, G. Kämpf, Steinbach-Giesen, Anabas.

Jarry, A., 1902: Le Surmâle. Roman moderne, Paris, Revue Blanche.

Lewis, W., 1914: The Melodrama of Modernity, "Blast. Review of the Great English Vortex" 1, pp. 143-144.

Macmonnies, F., 1915: French Artist Spur on American Art, "New York Tribune", October 24, [section 4], pp. 2- 3.

Maeterlinck, M., 1904a: Le Double jardin, Paris, Eugène Fasquele.

Maeterlinck, M., 1904b: In an Automobile, in Maeterlinck, M., The Double Garden, ed. by A. Teixeira de Mattos, transl. by A. Sutro, Dodd, Mead and Co., New York, pp. 171-186.

Marinetti, F.T. (ed.), 1914: I Manifesti del futurismo, Movimento Futurista, Milano.

Mertins, D., Jennings, M. (eds.), 2010: G. An Avant-garde Journal of Art, Architecture, Design, and Film, 1923-1926, Getty Research Institute, Los Angeles.

Moholy-Nagy, L., 1922: Produktion-Reproduktion, "De Stijl" 7, pp. 235-237.

Nietzsche, F., 1967-1982: Sämtliche Werke. Kritische Studienausgabe, 15 vols, ed. by G. Colli, M. Montinari, Walter de Gruyter, Frankfurt a.M.

Oyarzún, P., 2000: Anestética del ready-made, pref. by S. Rojas Contreras, Arcis lom, Santiago de Chile.

Picabia, F., 2005: Écrits critiques, ed. by C. Boulbès, pref. by B. Noël, Mémoire du Livre, Paris.

Rainey, L., Poggi, C., Wittman, L. (eds.), 2009: Futurism: An Anthology, Yale University Press, New Haven.

Roussel, R., 1910: Impressions d'Afrique, Lemerre, Paris.

Sanouillet, M., 1964: Picabia, Éditions du Temps, Paris.
Stieglitz, A., 1915-1916: 291, pp. 1-12.

Sweeney, J.J., 1946: Eleven Europeans in America, "Museum of Modern Art Bulletin", pp. 4-5. 